\title{
ANALISIS PERSIMPANGAN BERSINYAL PADA PERSIMPANGAN PATAL KOTA PALEMBANG
}

\author{
Darmadi, Ir
}

\begin{abstract}
Abstraksi
Kinerja Simpangan Patal saat ini tergolong buruk. Hal ini dapat dilihat dari Tingkat rata-rata Derajat jenuh (DS) 0.70, Panjang Antrian rata-rata mencapai 94,33 meter dan rata-rata waktu tundaan 57,46 smp/jam (ITP E). Penerapan Pelarangan Parkir disekitar kaki simpangan dapat meningkatkan kinerja suatu simpangan yang dapat diukur dari nilai Derajat Kejenuhan, Panjang Antrian dan waktu tundaan.
\end{abstract}

Kata kunci : Derajat jenuh(DS), 3 fase, 4 fase, kendaraan

\section{Latar Belakang}

Transportasi merupakan sarana yang sangat penting dan strategis untuk memperlancar pergerakan kebutuhan masyarakat. Tatanan transportasi yang terorganisasi secara kesisteman terdiri dari transportasi jalan, transportasi kereta api, transportasi sungai dan danau, transportasi penyeberangan, transportasi laut, transportasi pipa yang masing-masing terdiri dari sarana dan prasarana yang saling berinteraksi dengan dukungan perangkat lunak dan perangkat pikir membentuk suatu sistem pelayanan jasa transportasi yang baik berfungsi melayani perpindahan orang dan atau barang yang terus berkembang secara dinamis, sesuai dengan harapan dari sistem transportasi nasional.

Perencanaan dan pembangunan sarana dan prasarana transportasi, sangat mempengaruhi dan menentukan peningkatan pertumbuhan perekonomian dalam menunjang pencapaian sasaran pembangunan dan hasilhasilnya, yang berdampak nyata pada perubahan yang konstruktif dalam masyarakat disemua aspek kehidupan. Selain itu, situasi dan kondisi lingkungan mengalami perubahan yang fundamental kearah peningkatan yang lebih baik dan lebih maju, sehingga mampu meningkatkan taraf hidup masyarakat luas dan memperkuat stabilitas nasional.

Persimpangan merupakan pusat konflik dengan parameter semakin rapat jaringan jalan yang ada membuat mobilitas penduduk semakin tinggi dan membuat kota tumbuh lebih cepat, dengan semakin meningkatnya kepadatan penduduk maka meningkat pula kendaraan pribadi semakin padat pada ruas jalan kota. Persimpangan adalah bagian dari sistem jaringan jalan, yang secara umum kapasitas persimpangan dapat dikontrol dengan mengendalikan volume lalu lintas dalam sistem jaringan tersebut.

Kota Palembang dengan luas wilayah 470,236 $\mathrm{Km}^{2}$ dan mempunyai 16 kecamatan yang merupakan ibukota provinsi Sumatera selatan juga merasakan dampak dari hal tersebut. Kesemerawutan, tingginya derajat kejenuhan, besarnya waktu tunda serta panjangnya antrian di persimpangan Patal merupakan permasalahan serius yang harus segera diatasi.

Oleh karena itu, untuk mengatasi permasalahan tersebut di atas perlu adanya suatu kajian atau analisa mengenai kinerja simpangan tersebut. Untuk itulah pada kesempatan ini coba dibahas mengenai Kinerja Suatu Simpangan dengan menggunakan Manual Kapasitas Jalan Indonesia (MKJI). Tujuan 
penepitian ini untuk mengetahui volume lalu lintas, tundaan, derajat kejenuhan dan panjang antrian.

\section{Metode Penelitian}

Setelah ditentukan objek apa saja yang akan diteliti, maka dibuatlah suatu pendekatan untuk mendapatkan data tersebut yaitu:

Metode Institusional

Adalah dengan cara melakukan kunjungan ke instansi atau kantor untuk mendapatkan data sekunder yang berkaitan dengan penelitian yang dilakukan. Adapun instansi - instansi yang dikunjungi untuk mendapatkan data sekunder yaitu :

a) Kantor Badan Pusat Statistik Kota Palembang Untuk mendapatkan Rencana Tata Ruang Wilayah

b) Kantor Badan Perencanaan Pembangunan Daerah Untuk mendapatkan data tingkat pertumbuhan kendaraan

\section{Metode Survai}

Adalah dengan cara melakukan perhitungan, pengamatan serta pengukuran langsung untuk mendapatkan data Primer terkait kebutuhan data dalam penelitian. Survai yang dilakukan yaitu :

a. Survai Geometrik Jalan. Survai terhadap Geometrik Jalan ini dilakukan pada hari minggu tanggal 6 Pebruari 2011 yang meliputi pengukuran terhadap lebar jalan, lebar trotoar, lebar median. Alat ukur yang digunakan adalah meteran. dilihat pada Tabel 1 berikut ini:

Tabel 1. Data Geometrik Persimpangan Patal

\begin{tabular}{|c|c|c|c|c|c|c|c|c|}
\hline $\begin{array}{c}\text { Nama } \\
\text { Jalan }\end{array}$ & \multicolumn{2}{|c|}{$\begin{array}{c}\text { R. Sukamto } \\
(\mathrm{m})\end{array}$} & \multicolumn{2}{|c|}{$\begin{array}{c}\text { MP Mangkunegara } \\
(\mathrm{m})\end{array}$} & \multicolumn{2}{|c|}{$\begin{array}{c}\text { Abdul } \\
\text { Rozak }(\mathrm{m})\end{array}$} & \multicolumn{2}{|c|}{$\begin{array}{c}\text { AKBP Cek } \\
\text { Agus } \\
(\mathrm{m})\end{array}$} \\
\hline $\begin{array}{c}\text { Bahu } \\
\text { Jalan }\end{array}$ & - & - & 1,6 & 2,7 & 3,7 & - & - & 1,4 \\
\hline Trotoar & 1,41 & 1,45 & - & - & - & 1,2 & 2,1 & - \\
\hline Median & \multicolumn{2}{|c|}{0,57} & \multicolumn{2}{|c|}{-} & \multicolumn{2}{|c|}{1,71} & \multicolumn{2}{|c|}{-} \\
\hline $\begin{array}{c}\text { Lebar } \\
\text { Jalan }\end{array}$ & 7,8 & 9,37 & 11,9 & & 9,83 & 7,1 & 12,23 & \\
\hline
\end{tabular}

Sumber :Data Hasil Survai

b. Survai Arus Lalu Lintas. Waktu Survai Lalu Lintas dilakukan hanya 1 hari yaitu pada hari Senin tanggal 7 Pebruari 2011. Pemilihan hari senin dilakukan berdasarkan keterangan pegawai perhubungan dilokasi penelitian bahwa hari puncak arus kendaraan biasanya terjadi pada hari senin. Hal ini disebabkan karena pada hari tersebut merupahan hari peralihan dari hari libur menjadi hari kerja. Lokasi Survai Untuk Survai dilakukan pada kaki-kaki pada simpang patal untuk kendaraan yang belok kiri, belok kanan dan lurus.

c. Survai Kondisi Lingkungan. Survai ini dilakukan dengan pengamatan mengenai hambatan samping disekitar lokasi penelitian seperti kendaraan yang berhenti di kaki-kaki simpangan serta kios-kios dipinggir jalan. Selain itu juga 
dilakukan penghitungan terhadap APILL pada lokasi simpang patal untuk mengetahui waktu hijau dan waktu merah-nya. Dari data-data yang didapat baik dari hasil survai maupun Institusional maka dilakukan pengolahan terhadap data tersebut agar dapat mencapai tujuan yang diinginkan:

\section{Jam Sibuk Persimpangan}

Untuk menganalisis kinerja suatu simpang maka perlu untuk diketahui besarnya volume kendaraan dan jenis-jenis kendaraan yang melewatinya. Untuk itu dari data hasil survai mengenai Arus lalu lintas kendaraan pada ke-empat kaki pada Persimpangan Patal dibuat tabel dan diagram sebagai bahan untuk mempermudah penganalisaan kinerja simpang. Adapun volume puncak kendaraan dapat dilihat pada tabel berikut :

Tabel 2. Volume Kendaraan Perjam

\begin{tabular}{|c|c|}
\hline Jam & $\begin{array}{c}\text { Volume Kendaraan } \\
\text { (smp/jam) }\end{array}$ \\
\hline $06: 00-07: 00$ & 3442 \\
\hline 07:00 - 08:00 & 3665 \\
\hline $08: 00-09: 00$ & 3589 \\
\hline $11: 00-12: 00$ & 3353 \\
\hline $12: 00-13: 00$ & 3379 \\
\hline $13: 00-14: 00$ & 3331 \\
\hline $15: 00-16: 00$ & 3385 \\
\hline $16: 00-17: 00$ & 3576 \\
\hline $17: 00-18: 00$ & 3559 \\
\hline
\end{tabular}

Sumber : Hasil Analisis

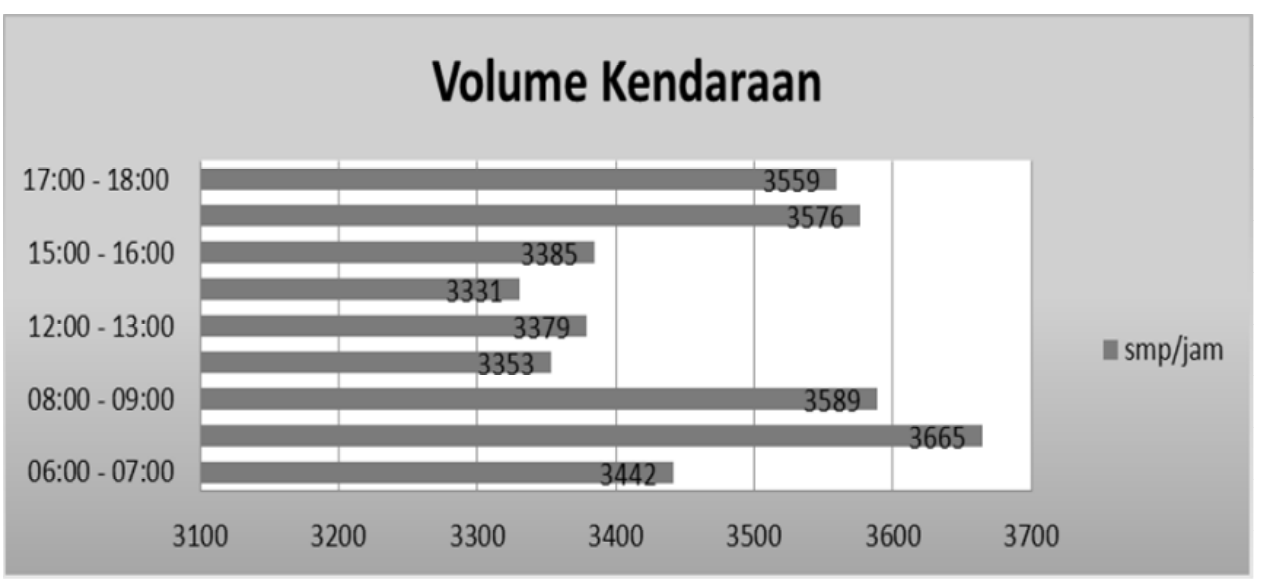

Gambar 1. Volume Kendaraan pada Persimpangan Patal

Dari gambar diatas dapat dilihat bahwa waktu puncak pada pagi hari terjadi pada pukul 07:00 - 08:00 dengan 3665 smp/jam sedangkan waktu puncak siang terjadi pada pukul 12:00 - 13:00 dengan 3379 smp/jam dan waktu puncak sore hari pada pukul 16:00 - 17:00 dengan $3576 \mathrm{smp} / \mathrm{jam}$. 
Dari data tersebut diatas dapat diklasifikasikan berdasarkan jenis kendaraan sesuai dengan gambar berikut :

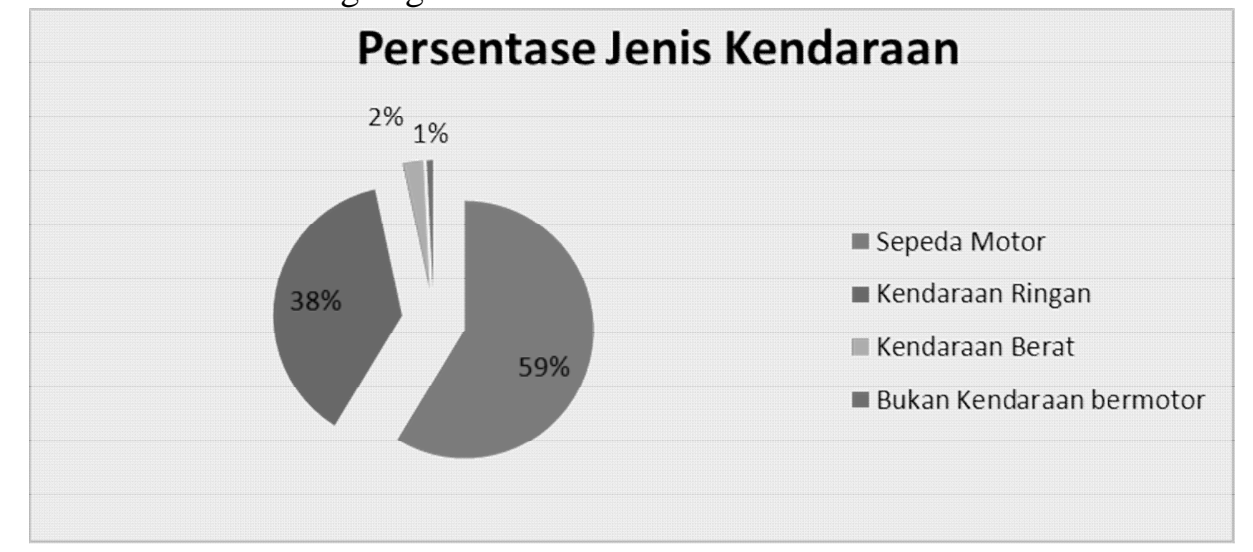

Gambar 2. Jenis-Jenis Kendaraan pada Persimpangan Patal

Dari keterangan pada gambar-gambar diatas kemudian dapat ditentukan rencana pengaturan untuk APILL ;

1) Rencana I : $6.00-9.00$

Dalam periode 6.00 sampai dengan 9.00 dijadikan dalam satu Rencana yang sama dikarenakan periode itu merupakan waktu sibuk pagi.

2) Rencana II : $11.00-14.00$

Dalam periode 11.00 sampai dengan 14.00 dijadikan dalam satu Rencana yang sama dikarenakan periode ini merupakan waktu sibuk siang.

3) Rencana III : $15.00-18.00$

Dalam periode 15.00 sampai dengan 18.00 dijadikan dalam satu Rencana yang sama dikarenakan periode ini merupakan waktu sore

Pada simpang Patal sendiri, pengaturan lampu lalu lintas pada kondisi eksisting adalah statis sepanjang hari (belum berdasarkan perubahan lalu lintas yang terjadi), sedangkan pengaturan fasenya adalah 4 fase. Adapun perincian sebagai berikut :

1) Pendekat utara, dengan waktu hijau 27 detik, kuning 3 detik, dan merah 146 detik

2) Pendekat selatan, dengan waktu hijau 27 detik, kuning 3 detik, dan merah 172 detik

3) Pendekat timur, dengan waktu hijau 27 detik, kuning 3 detik, dan merah 160 detik.

4) Pendekat barat, dengan waktu hijau 40 detik, kuning 3 detik, dan merah 185 detik.

Pada sekitar persimpangan juga ditemui beberapa kendaraan yang parkir dengan menggunakan badan jalan ;

1) Pada pendekat sebelah utara, jarak antara garis henti dengan kendaraan yang diparkir pertama adalah $10 \mathrm{~m}$

2) Pada pendekat sebelah selatan, jarak antara garis henti dengan kendaraan yang diparkir pertama adalah $10 \mathrm{~m}$ 
3) Pada pendekat sebelah timur, jarak antara garis henti dengan kendaraan yang diparkir pertama adalah $15 \mathrm{~m}$

4) Pada pendekat sebelah barat, jarak antara garis henti dengan kendaraan yang diparkir pertama adalah $25 \mathrm{~m}$

\section{Analisis Kinerja Simpang Kondisi Eksisting}

a. Penghitungan Panjang Antrian (QL)

Untuk menghitung panjang antrian kendaraan di hitung dengan menggunakan rumus seperti dibawah ini

$$
\begin{aligned}
\mathrm{QL} & =\frac{\mathrm{NQ}_{\mathrm{MAX}} \times 20}{\mathrm{~W}_{\text {MASUK }}} \\
& =27 \times 20 / 5,95=89,81 \mathrm{~m}
\end{aligned}
$$

Lebih lengkapnya mengenai Penghitungan nilai QL bisa dilihat pada tabel dibawah ini

Tabel 3. Penghitungan Panjang Antrian (QL)

\begin{tabular}{|c|c|c|c|c|}
\hline No & Pendekatan & $\begin{array}{c}\text { NQ Max } \\
(\mathrm{smp})\end{array}$ & $\begin{array}{c}\text { Lebar Masuk } \\
\mathrm{W}_{\text {MASUK }}(\mathrm{m})\end{array}$ & $\begin{array}{c}\text { Panjang Antrian } \\
\text { QL }(\mathrm{m})\end{array}$ \\
\hline 1 & $\mathrm{U}$ & 27 & 5,95 & 89,81 \\
\hline 2 & $\mathrm{~S}$ & 26 & 6,115 & 85,68 \\
\hline 3 & $\mathrm{~T}$ & 29 & 7,1 & 82,46 \\
\hline 4 & $\mathrm{~B}$ & 56 & 9,37 & 119,02 \\
\hline
\end{tabular}

Sumber : Hasil Analisis

b. Penghitungan Tundaan Rata-rata Simpang $\left(D_{I}\right)$

Untuk menghitung Tundaan Rata-rata Simpang digunakan rumus seperti dibawah ini

$$
\begin{aligned}
\mathrm{D}_{\mathrm{I}} & =\frac{\sum(\mathrm{Q} x(\mathrm{DT}+\mathrm{DG}))}{\mathrm{Q}_{\text {TOT }}} \\
& =117.214,143 / 2006=58,44 \text { detik }
\end{aligned}
$$

\begin{tabular}{|c|c|c|c|c|c|c|c|}
\hline No & Pendekat & $\begin{array}{c}\text { Tundaan } \\
\text { LL } \\
\text { DT } \\
\text { (smp/detik) }\end{array}$ & $\begin{array}{c}\text { Tundaan } \\
\text { geometri } \\
\text { DG } \\
\text { (smp/detik) }\end{array}$ & \begin{tabular}{|c}
$\begin{array}{c}\text { Tundaan } \\
\text { Total }\end{array}$ \\
D \\
(smp/detik)
\end{tabular} & $\begin{array}{c}\text { Arus } \\
\mathrm{Q} \\
\text { (smp/jam) }\end{array}$ & $Q \times D$ & $\begin{array}{c}\text { Tundaan } \\
\text { rata-rata } \\
\text { simpang } \\
\left(D_{\mathrm{I}}\right) \\
\text { (smp/detik) }\end{array}$ \\
\hline 1 & $\mathrm{U}$ & 65,776 & 4,000 & 69,776 & 411 & 28656,348 & \multirow[t]{4}{*}{58,44} \\
\hline 2 & $\mathrm{~S}$ & 65,054 & 4,000 & 69,054 & 398 & 27475,127 & \\
\hline 3 & $\mathrm{~T}$ & 55,836 & 4,000 & 59,836 & 422 & 25256,896 & \\
\hline 4 & B & 42,221 & 4,000 & 46,221 & 775 & 35825,772 & \\
\hline & & & & Total & 2006 & $117.214,143$ & \\
\hline
\end{tabular}

Lebih lengkapnya mengenai Penghitungan Rata-rata Simpang bisa dilihat pada tabel dibawah ini

Tabel 4. Penghitungan Tundaan Rata-rata Simpang $\left(\mathrm{D}_{\mathrm{I}}\right)$

Sumber : Hasil analisis 
c. Penghitungan Derajat Kejenuhan (DS)

Derajat kejenuhan dapat di hitung dengan menggunakan rumus seperti yang tercantum dibawah ini.

$$
\begin{aligned}
\mathrm{DS} & =\frac{\mathrm{Q}_{\mathrm{TOT}}}{\mathrm{C}} \\
& =\frac{382}{491,685} \\
& =0,777
\end{aligned}
$$

Lebih lengkapnya mengenai Penghitungan Derajat Kejenuhan (DS) bisa dilihat pada tabel dibawah ini

Tabel 5. Penghitungan Derajat Kejenuhan (DS)

\begin{tabular}{|c|c|c|c|c|}
\hline No. & Pendekat & $\begin{array}{c}\text { Arus } \\
\mathrm{Q} \\
(\mathrm{smp} / \mathrm{jam})\end{array}$ & $\begin{array}{c}\text { kapasitas } \\
\mathrm{C} \\
(\mathrm{smp} / \mathrm{jam})\end{array}$ & $\begin{array}{c}\text { Derajat } \\
\text { kejenuhan } \\
\mathrm{DS}\end{array}$ \\
\hline 1 & $\mathrm{U}$ & 382 & 491,685 & 0,777 \\
\hline 2 & $\mathrm{~S}$ & 448 & 505,948 & 0,885 \\
\hline 3 & $\mathrm{~T}$ & 441 & 602,716 & 0,731 \\
\hline 4 & $\mathrm{~B}$ & 801 & 1316,929 & 0,608 \\
\hline
\end{tabular}

Sumber : Hasil Analisis

d. Penghitungan Panjang Antrian (QL)

Untuk menghitung panjang antrian kendaraan di hitung dengan menggunakan rumus seperti dibawah ini

$$
\begin{aligned}
\mathrm{QL} & =\frac{\mathrm{NQ}_{\text {MAX }} \times 20}{\mathrm{~W}_{\text {MASUK }}} \\
& =26 \times 20 / 5,95 \\
& =87 \mathrm{~m}
\end{aligned}
$$

Lebih lengkapnya mengenai Penghitungan nilai QL bisa dilihat pada tabel dibawah ini

Tabel 6. Penghitungan Panjang Antrian (QL)

\begin{tabular}{|c|c|c|c|c|}
\hline No & Pendekat & $\begin{array}{c}\text { NQ } \\
\text { maks } \\
(\mathrm{smp})\end{array}$ & $\begin{array}{c}\text { Lebar } \\
\text { masuk } \\
\mathrm{W}_{\mathrm{A}}(\mathrm{m})\end{array}$ & $\begin{array}{c}\text { Panjang } \\
\text { Antrian } \\
\text { QL (m) }\end{array}$ \\
\hline 1 & $\mathrm{U}$ & 26 & 5,95 & 87 \\
\hline 2 & $\mathrm{~S}$ & 28 & 6,115 & 93 \\
\hline 3 & $\mathrm{~T}$ & 30 & 7,1 & 84 \\
\hline 4 & $\mathrm{~B}$ & 56 & 9,37 & 120 \\
\hline
\end{tabular}

Sumber : Hasil Analisis 


\section{Analisis Kinerja Simpang Dengan 4 Fase Dan Dengan Larangan Parkir}

Dalam analisa ini, dicoba menganalisa kinerja simpang Patal dengan menggunakan jumlah fase yang sama terhadap kondisi eksisting yaitu sejumlah 4 fase, tetapi dengan menerapkan larangan parkir dari tiap-tiap garis henti pada tiap-tiap pendekat. Untuk Pendekatan Utara dan Selatan dibuat larangan parkir sejauh 75 meter dengan alasan pada jarak tersebut terdapat jalan keluar masuk kendaraan. Untuk pendekatan Timur jarak yang diambil yaitu 120 meter dengan alasan terdapat U-turn pada jarak itu sedangkan untuk pendekatan Barat jarak yang diambil adalah 170 meter dengan alasan U-turn.

Penghitungan Derajat Kejenuhan (DS)

Tabel 7. Penghitungan Derajat Kejenuhan (DS)

\begin{tabular}{|c|c|c|c|c|}
\hline No. & Pendekat & $\begin{array}{c}\text { Arus } \\
\mathrm{Q} \\
(\mathrm{smp} / \mathrm{jam})\end{array}$ & $\begin{array}{c}\text { kapasitas } \\
\mathrm{C} \\
(\mathrm{smp} / \mathrm{jam})\end{array}$ & $\begin{array}{c}\text { Derajat } \\
\text { kejenuhan } \\
\mathrm{DS}\end{array}$ \\
\hline 1 & $\mathrm{U}$ & 411 & 681 & 0,603 \\
\hline 2 & $\mathrm{~S}$ & 398 & 704 & 0,565 \\
\hline 3 & $\mathrm{~T}$ & 422 & 875 & 0,482 \\
\hline 4 & $\mathrm{~B}$ & 775 & 1474 & 0,526 \\
\hline
\end{tabular}

Sumber : Hasil Analisis

Penghitungan Panjang Antrian (QL)

Tabel 8. Penghitungan Panjang Antrian (QL)

\begin{tabular}{|c|c|c|c|c|}
\hline No & Pendekat & $\begin{array}{c}\text { NQ } \\
\text { maks } \\
(\mathrm{smp})\end{array}$ & $\begin{array}{c}\text { Lebar } \\
\text { masuk } \\
\mathrm{W}_{\mathrm{A}}(\mathrm{m})\end{array}$ & $\begin{array}{c}\text { Panjang } \\
\text { Antrian } \\
\text { QL }(\mathrm{m})\end{array}$ \\
\hline 1 & $\mathrm{U}$ & 23 & 5,95 & 78 \\
\hline 2 & $\mathrm{~S}$ & 24 & 6,12 & 77 \\
\hline 3 & $\mathrm{~T}$ & 28 & 7,10 & 78 \\
\hline 4 & $\mathrm{~B}$ & 43 & 9,37 & 91 \\
\hline
\end{tabular}

Sumber : Hasil Analisis

Penghitungan Tundaan Rata-rata Simpang (DI)

Tabel 9. Penghitungan Tundaan Rata-rata Simpang $\left(D_{I}\right)$

\begin{tabular}{|c|c|c|c|c|c|c|c|}
\hline No & Pendekat & $\begin{array}{c}\text { Tundaan LL } \\
\text { DT } \\
\text { (smp/detik) }\end{array}$ & \begin{tabular}{|c|} 
Tundaan \\
geometri \\
DG \\
(smp/detik) \\
\end{tabular} & $\begin{array}{c}\text { Tundaan } \\
\text { Total } \\
\text { D } \\
\text { (smp/detik) }\end{array}$ & $\begin{array}{c}\text { Arus } \\
\mathrm{Q} \\
\text { (smp/jam) }\end{array}$ & Q x D & \begin{tabular}{|c|} 
Tundaan \\
rata-rata \\
simpang $\left(D_{\mathrm{I}}\right)$ \\
$($ smp/detik $)$ \\
\end{tabular} \\
\hline 1 & U & 34,288 & 4,000 & 38,288 & 411 & 15724,479 & \multirow[t]{4}{*}{36,01} \\
\hline 2 & $S$ & 32,614 & 4,000 & 36,614 & 398 & 14567,801 & \\
\hline 3 & $\mathrm{~T}$ & 31,953 & 4,000 & 35,953 & 422 & 15175,677 & \\
\hline 4 & B & 30,528 & 4,000 & 34,528 & 775 & 26762,301 & \\
\hline & & & & Total & 2006 & 72230,259 & \\
\hline
\end{tabular}


Penghitungan Derajat Kejenuhan (DS)

Tabel 10. Penghitungan Derajat Kejenuhan (DS)

\begin{tabular}{|c|c|c|c|c|}
\hline No. & Pendekat & $\begin{array}{c}\text { Arus } \\
\text { Q } \\
(\text { smp/jam })\end{array}$ & $\begin{array}{c}\text { kapasitas } \\
\text { C } \\
(\text { smp/jam })\end{array}$ & $\begin{array}{c}\text { Derajat } \\
\text { kejenuhan } \\
\text { DS }\end{array}$ \\
\hline 1 & $\mathrm{U}$ & 346 & 630 & 0,55 \\
\hline 2 & $\mathrm{~S}$ & 336 & 664 & 0,51 \\
\hline 3 & $\mathrm{~T}$ & 412 & 947 & 0,44 \\
\hline 4 & $\mathrm{~B}$ & 514 & 1.445 & 0,36 \\
\hline
\end{tabular}

Sumber : Hasil Analisis

Penghitungan Panjang Antrian (QL)

Tabel 11. Penghitungan Panjang Antrian (QL)

\begin{tabular}{|c|c|c|c|c|}
\hline No & Pendekat & $\begin{array}{c}\text { NQ } \\
\text { maks } \\
(\mathrm{smp})\end{array}$ & $\begin{array}{c}\text { Lebar } \\
\text { masuk } \\
\mathrm{W}_{\mathrm{A}}(\mathrm{m})\end{array}$ & $\begin{array}{c}\text { Panjang } \\
\text { Antrian } \\
\mathrm{QL}(\mathrm{m})\end{array}$ \\
\hline 1 & $\mathrm{U}$ & 20 & 5,95 & 67 \\
\hline 2 & $\mathrm{~S}$ & 21 & 6,12 & 68 \\
\hline 3 & $\mathrm{~T}$ & 27 & 7,10 & 76 \\
\hline 4 & $\mathrm{~B}$ & 38 & 9,37 & 81 \\
\hline
\end{tabular}

Sumber : Hasil Analisis

Penghitungan Tundaan Rata-rata Simpang $\left(D_{I}\right)$

Tabel 12. Penghitungan Tundaan Rata-rata Simpang ( $\left.\mathrm{D}_{\mathrm{I}}\right)$

\begin{tabular}{|c|c|c|c|c|c|c|c|}
\hline No & Pendekat & $\begin{array}{c}\text { Tundaan } \\
\text { LL } \\
\text { DT } \\
\text { (smp/detik) }\end{array}$ & $\begin{array}{c}\text { Tundaan } \\
\text { geometri } \\
\text { DG } \\
\text { (smp/detik) }\end{array}$ & $\begin{array}{c}\text { Tundaan } \\
\text { Total } \\
\text { D } \\
\text { (smp/detik) }\end{array}$ & $\begin{array}{c}\text { Arus } \\
\text { Q } \\
\text { (smp/jam) }\end{array}$ & $Q \times D$ & $\begin{array}{l}\text { Tundaan } \\
\text { rata-rata } \\
\text { simpang }\left(D_{\mathrm{I}}\right) \\
(\text { smp/detik) }\end{array}$ \\
\hline 1 & $\mathrm{U}$ & 30 & 4,00 & 34 & 346 & 11.834 & \multirow[t]{4}{*}{32,02} \\
\hline 2 & $\mathrm{~S}$ & 29 & 4,00 & 33 & 336 & 11.097 & \\
\hline 3 & $\mathrm{~T}$ & 28 & 4,00 & 32 & 412 & 12.990 & \\
\hline 4 & $\mathrm{~B}$ & 26 & 4,00 & 30 & 514 & 15.561 & \\
\hline & & & & Total & 1.608 & 51.482 & \\
\hline
\end{tabular}

Sumber : Hasil Analisis

Penghitungan Derajat Kejenuhan (DS)

Tabel 13. Penghitungan Derajat Kejenuhan (DS)

\begin{tabular}{|c|c|c|c|c|}
\hline No. & Pendekat & $\begin{array}{c}\text { Arus } \\
\text { Q } \\
(\mathrm{smp} / \mathrm{jam})\end{array}$ & $\begin{array}{c}\text { kapasitas } \\
\mathrm{C} \\
(\mathrm{smp} / \mathrm{jam})\end{array}$ & $\begin{array}{c}\text { Derajat } \\
\text { kejenuhan } \\
\mathrm{DS}\end{array}$ \\
\hline 1 & $\mathrm{U}$ & 382 & 683 & 0,559 \\
\hline 2 & $\mathrm{~S}$ & 448 & 788 & 0,568 \\
\hline 3 & $\mathrm{~T}$ & 441 & 834 & 0,528 \\
\hline 4 & $\mathrm{~B}$ & 801 & 1437 & 0,557 \\
\hline
\end{tabular}


Penghitungan Panjang Antrian (QL)

Tabel 14. Penghitungan Panjang Antrian (QL)

\begin{tabular}{|c|c|c|c|c|}
\hline No & Pendekat & $\begin{array}{c}\text { NQ } \\
\text { maks } \\
(\mathrm{smp})\end{array}$ & $\begin{array}{c}\text { Lebar } \\
\text { masuk } \\
\mathrm{W}_{\mathrm{A}}(\mathrm{m})\end{array}$ & $\begin{array}{c}\text { Panjang } \\
\text { Antrian } \\
\text { QL (m) }\end{array}$ \\
\hline 1 & $\mathrm{U}$ & 23 & 5,95 & 77 \\
\hline 2 & $\mathrm{~S}$ & 25 & 6,115 & 83 \\
\hline 3 & $\mathrm{~T}$ & 27 & 7,1 & 75 \\
\hline 4 & $\mathrm{~B}$ & 41 & 9,37 & 88 \\
\hline
\end{tabular}

Sumber : Hasil Analisis

Penghitungan Tundaan Rata-rata Simpang $\left(D_{I}\right)$

Tabel 15. Penghitungan Tundaan Rata-rata Simpang $\left(D_{I}\right)$

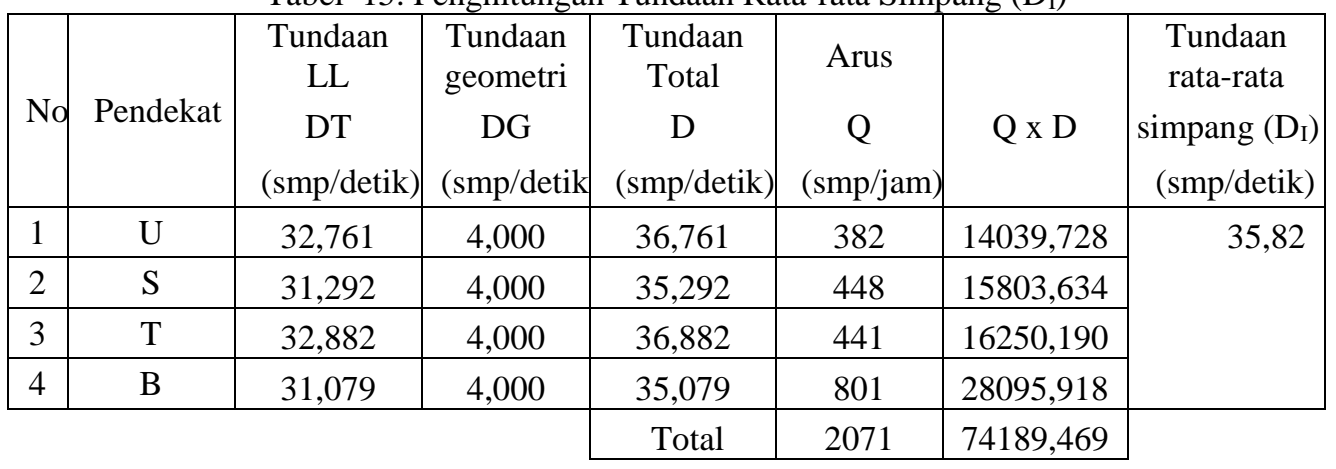

Sumber : Hasil Analisis

\section{Analisis Kinerja Simpang Dengan 3 Fase Dan Dengan Larangan Parkir}

Setelah dianalisa dengan menggunakan fase yang eksiting dan diberikan larangan parkir, Kali ini dicoba dengan merubah fase menjadi 3 fase dan tetap diberikan larangan parkir. Perubahan 3 fase ini menyebabkan ada arus yang di adu (oppose). Untuk itu akan diberlakukan larangan belok untuk pendekatan Utara dan Pendekatan Selatan.

Tabel 16. Penghitungan Derajat Kejenuhan (DS)

\begin{tabular}{|c|c|c|c|c|}
\hline No. & Pendekat & $\begin{array}{c}\text { Arus } \\
\text { Q } \\
(\text { smp/jam })\end{array}$ & $\begin{array}{c}\text { kapasitas } \\
\text { C } \\
(\text { smp/jam })\end{array}$ & $\begin{array}{c}\text { Derajat } \\
\text { kejenuhan } \\
\text { DS }\end{array}$ \\
\hline 1 & $\mathrm{U}$ & 172 & 640,517 & 0,268 \\
\hline 2 & $\mathrm{~S}$ & 276 & 658,512 & 0,420 \\
\hline 3 & $\mathrm{~T}$ & 661 & 1377,954 & 0,480 \\
\hline 4 & $\mathrm{~B}$ & 896 & 1916,691 & 0,468 \\
\hline
\end{tabular}

Sumber : Hasil Analisis 
Penghitungan Tundaan Lalu lintas (DT)

Tabel 17. Penghitungan Tundaan Lalu lintas (DT)

\begin{tabular}{|c|c|c|c|c|c|c|c|c|}
\hline No & Pendekat & $\begin{array}{c}\text { Waktu } \\
\text { siklus } \\
\text { c } \\
\text { (detik) }\end{array}$ & $\begin{array}{c}\text { Rasio } \\
\text { Hijau } \\
\text { GR } \\
\text { g/c }\end{array}$ & $\begin{array}{c}\text { Derajat } \\
\text { Kejenuhan } \\
\text { DS }\end{array}$ & A & $\begin{array}{c}\text { kapasitas } \\
\text { C } \\
\text { (smp/jam }\end{array}$ & 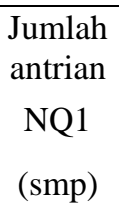 & $\begin{array}{c}\text { Tundaan } \\
\text { LL } \\
\text { DT } \\
\text { (smp/detik) }\end{array}$ \\
\hline 1 & U & \multirow{4}{*}{48} & 0,193 & 0,268 & 0,343 & 640,517 & 0,000 & 16,528 \\
\hline 2 & $\mathrm{~S}$ & & 0,193 & 0,420 & 0,354 & 658,512 & 0,000 & 17,056 \\
\hline 3 & $\mathrm{~T}$ & & 0,308 & 0,480 & 0,281 & 1377,954 & 0,000 & 13,548 \\
\hline 4 & B & & 0,250 & 0,468 & 0,318 & 1916,691 & 0,000 & 15,342 \\
\hline
\end{tabular}

Sumber : Hasil Analisis

Penghitungan Tundaan Rata-rata Simpang $\left(D_{I}\right)$

Tabel 18. Penghitungan Tundaan Rata-rata Simpang $\left(D_{I}\right)$

\begin{tabular}{|c|c|c|c|c|c|c|c|}
\hline No & Pendekat & $\begin{array}{c}\text { Tundaan } \\
\text { LL } \\
\text { DT } \\
\text { (smp/detik) } \\
\end{array}$ & \begin{tabular}{|c|} 
Tundaan \\
geometri \\
DG \\
(smp/detik) \\
\end{tabular} & $\begin{array}{c}\text { Tundaan } \\
\text { Total } \\
\text { D } \\
\text { (smp/detik) }\end{array}$ & $\begin{array}{c}\text { Arus } \\
\mathrm{Q} \\
\text { (smp/jam) }\end{array}$ & $Q \times D$ & $\begin{array}{c}\text { Tundaan } \\
\text { rata-rata } \\
\text { simpang }\left(D_{\mathrm{I}}\right) \\
(\mathrm{smp} / \text { detik) }\end{array}$ \\
\hline 1 & $\mathrm{U}$ & 16,528 & 4,000 & 20,528 & 172 & 3526,583 & \multirow[t]{4}{*}{19,09} \\
\hline 2 & $\mathrm{~S}$ & 17,056 & 4,000 & 21,056 & 276 & 5821,554 & \\
\hline 3 & $\mathrm{~T}$ & 13,548 & 4,000 & 17,548 & 661 & 11600,967 & \\
\hline 4 & $\mathrm{~B}$ & 15,342 & 4,000 & 19,342 & 896 & 17332,187 & \\
\hline & & & & Total & 2005 & 38281,291 & \\
\hline
\end{tabular}

Sumber : Hasil Analisis

Penghitungan Derajat Kejenuhan (DS)

Tabel 19. Penghitungan Derajat Kejenuhan (DS)

\begin{tabular}{|c|c|c|c|c|}
\hline No. & Pendekat & $\begin{array}{c}\text { Arus } \\
\mathrm{Q} \\
(\mathrm{smp} / \mathrm{jam})\end{array}$ & $\begin{array}{c}\text { kapasitas } \\
\mathrm{C} \\
(\mathrm{smp} / \mathrm{jam})\end{array}$ & $\begin{array}{c}\text { Derajat } \\
\text { kejenuhan } \\
\mathrm{DS}\end{array}$ \\
\hline 1 & $\mathrm{U}$ & 175 & 534,418 & 0,328 \\
\hline 2 & $\mathrm{~S}$ & 133 & 549,432 & 0,242 \\
\hline 3 & $\mathrm{~T}$ & 702 & 897,760 & 0,782 \\
\hline 4 & $\mathrm{~B}$ & 948 & 2191,945 & 0,433 \\
\hline
\end{tabular}

Sumber : Hasil Analisis 
Penghitungan Panjang Antrian (QL)

Tabel 20. Penghitungan Panjang Antrian (QL)

\begin{tabular}{|c|c|c|c|c|}
\hline No & Pendekat & $\begin{array}{c}\text { NQ } \\
\text { Maks } \\
(\mathrm{smp})\end{array}$ & $\begin{array}{c}\text { Lebar } \\
\text { masuk } \\
\mathrm{W}_{\mathrm{A}}(\mathrm{m})\end{array}$ & $\begin{array}{c}\text { Panjang } \\
\text { Antrian } \\
\text { QL (m) }\end{array}$ \\
\hline 1 & $\mathrm{U}$ & 12 & 5,95 & 41 \\
\hline 2 & $\mathrm{~S}$ & 12 & 6,115 & 40 \\
\hline 3 & $\mathrm{~T}$ & 17 & 7,1 & 49 \\
\hline 4 & $\mathrm{~B}$ & 31 & 9,37 & 66 \\
\hline
\end{tabular}

Penghitungan Tundaan Rata-rata Simpang $\left(D_{I}\right)$

Tabel 21. Penghitungan Tundaan Rata-rata Simpang $\left(D_{I}\right)$

\begin{tabular}{|c|c|c|c|c|c|c|c|}
\hline No & Pendekat & $\begin{array}{c}\text { Tundaan } \\
\text { LL } \\
\text { DT } \\
\text { (smp/detik) }\end{array}$ & $\begin{array}{c}\text { Tundaan } \\
\text { geometri } \\
\text { DG } \\
\text { (smp/detik }\end{array}$ & 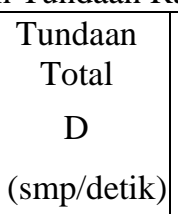 & $\begin{array}{c}\text { Arus } \\
\mathrm{Q} \\
\text { (smp/jam) }\end{array}$ & $Q \times D$ & $\begin{array}{c}\text { Tundaan } \\
\text { rata-rata } \\
\text { simpang }\left(D_{\mathrm{I}}\right) \\
\text { (smp/detik) }\end{array}$ \\
\hline 1 & $\mathrm{U}$ & 15,131 & 4,000 & 19,131 & 175 & 3349,122 & \multirow[t]{4}{*}{18,89} \\
\hline 2 & $S$ & 14,915 & 4,000 & 18,915 & 133 & 2518,693 & \\
\hline 3 & $\mathrm{~T}$ & 20,646 & 4,000 & 24,646 & 702 & 17291,917 & \\
\hline 4 & $\mathrm{~B}$ & 10,574 & 4,000 & 14,574 & 948 & 13823,308 & \\
\hline & & & & Total & 1958 & 36983,040 & \\
\hline
\end{tabular}

Penghitungan Derajat Kejenuhan (DS)

Tabel 22. Penghitungan Derajat Kejenuhan (DS)

\begin{tabular}{|c|c|c|c|c|}
\hline No. & Pendekat & $\begin{array}{c}\text { Arus } \\
\mathrm{Q} \\
(\mathrm{smp} / \mathrm{jam})\end{array}$ & $\begin{array}{c}\text { kapasitas } \\
\mathrm{C} \\
(\mathrm{smp} / \mathrm{jam})\end{array}$ & $\begin{array}{c}\text { Derajat } \\
\text { kejenuhan } \\
\mathrm{DS}\end{array}$ \\
\hline 1 & $\mathrm{U}$ & 149 & 601,721 & 0,248 \\
\hline 2 & $\mathrm{~S}$ & 212 & 618,626 & 0,342 \\
\hline 3 & $\mathrm{~T}$ & 674 & 1297,292 & 0,519 \\
\hline 4 & $\mathrm{~B}$ & 1037 & 2000,956 & 0,518 \\
\hline
\end{tabular}

\section{Penghitungan Panjang Antrian (QL)}

Tabel 23. Penghitungan Panjang Antrian (QL)

\begin{tabular}{|c|c|c|c|c|}
\hline No & Pendekat & $\begin{array}{c}\text { NQ } \\
\text { maks } \\
(\mathrm{smp})\end{array}$ & $\begin{array}{c}\text { Lebar } \\
\text { masuk } \\
\mathrm{W}_{\mathrm{A}}(\mathrm{m})\end{array}$ & $\begin{array}{c}\text { Panjang } \\
\text { Antrian } \\
\mathrm{QL}(\mathrm{m})\end{array}$ \\
\hline 1 & $\mathrm{U}$ & 14 & 5,95 & 48 \\
\hline 2 & $\mathrm{~S}$ & 15 & 6,115 & 47 \\
\hline 3 & $\mathrm{~T}$ & 24 & 7,1 & 67 \\
\hline 4 & $\mathrm{~B}$ & 34 & 9,37 & 72 \\
\hline
\end{tabular}


Penghitungan Tundaan Rata-rata Simpang $\left(D_{I}\right)$

Tabel 24. Penghitungan Tundaan Rata-rata Simpang ( $\left.D_{I}\right)$

\begin{tabular}{|c|c|c|c|c|c|c|c|}
\hline No & Pendekat & $\begin{array}{c}\text { Tundaan } \\
\text { LL } \\
\text { DT } \\
\text { (smp/detik) }\end{array}$ & $\begin{array}{l}\text { Tundaan } \\
\text { geometri } \\
\text { DG } \\
\text { (smp/detik) }\end{array}$ & $\begin{array}{c}\text { Tundaan } \\
\text { Total } \\
\text { D } \\
\text { (smp/detik) }\end{array}$ & $\begin{array}{c}\text { Arus } \\
\mathrm{Q} \\
\text { (smp/jam) }\end{array}$ & $Q \times D$ & $\begin{array}{c}\text { Tundaan } \\
\text { rata-rata } \\
\text { simpang }\left(D_{\mathrm{I}}\right) \\
\text { (smp/detik) }\end{array}$ \\
\hline 1 & $\mathrm{U}$ & 17,373 & 4,000 & 21,373 & 149 & 3191,587 & \multirow[t]{4}{*}{19,11} \\
\hline 2 & $\mathrm{~S}$ & 17,688 & 4,000 & 21,688 & 212 & 4587,022 & \\
\hline 3 & $\mathrm{~T}$ & 14,990 & 4,000 & 18,990 & 674 & 12791,683 & \\
\hline 4 & B & 14,344 & 4,000 & 18,344 & 1037 & 19021,782 & \\
\hline & & & & Total & 2071 & 39592,073 & \\
\hline
\end{tabular}

Sumber : Hasil Analisis

Tabel 25. Tabel Perbandingan Besaran Tundaan

\begin{tabular}{|c|c|c|c|}
\hline \multirow{2}{*}{ KONDISI } & \multicolumn{3}{|c|}{ Tundaan (detik/smp) } \\
\cline { 2 - 4 } & PAGI & SIANG & SORE \\
\hline Kondisi Saat Ini & 58,44 & 53,97 & 59,98 \\
\hline 4 Fase Dengan Pelarangan Parkir & 36,01 & 32,02 & 35,82 \\
\hline 3 Fase Dengan Pelarangan Parkir & 19,09 & 18,89 & 19,11 \\
\hline
\end{tabular}

Sumber : Hasil Analisis

Tabel 26. Tabel Perbandingan Besaran Derajat Kejenuhan

\begin{tabular}{|c|c|c|c|c|c|c|c|c|c|c|c|c|}
\hline \multirow{3}{*}{ Kondisi } & \multicolumn{12}{|c|}{ Derajat Kejenuhan } \\
\hline & \multicolumn{4}{|c|}{ Pagi } & \multicolumn{4}{|c|}{ Siang } & \multicolumn{4}{|c|}{ Sore } \\
\hline & $\mathrm{U}$ & $S$ & $\mathrm{~T}$ & $\mathrm{~B}$ & $\mathrm{U}$ & $\mathrm{S}$ & $\mathrm{T}$ & B & $\mathrm{U}$ & $\mathrm{S}$ & $\mathrm{T}$ & B \\
\hline $\begin{array}{ll}\text { Kondisi saat } \\
\text { ini }\end{array}$ & 0,83 & 0,82 & 0,71 & 0,60 & 0,72 & 0,67 & 0,68 & 0,39 & 0,78 & 0,89 & 0,73 & 0,61 \\
\hline $\begin{array}{l}4 \text { fase dengan } \\
\text { pelarangan } \\
\text { parkir }\end{array}$ & 0,60 & 0,56 & 0,48 & 0,53 & 0,55 & 0,51 & 0,44 & 0,36 & 0,56 & 0,57 & 0,53 & 0,56 \\
\hline $\begin{array}{l}3 \text { fase dengan } \\
\text { pelarangan } \\
\text { parkir }\end{array}$ & 0,27 & 0,42 & 0,48 & 0,47 & 0,33 & 0,24 & 0,78 & 0,43 & 0,25 & 0,34 & 0,52 & 0,52 \\
\hline
\end{tabular}

Sumber : Hasil Analisis 
Tabel 27. Tabel Perbandingan Panjang Antrian

\begin{tabular}{|c|c|c|c|c|c|c|c|c|c|c|c|c|}
\hline \multirow{3}{*}{ KONDISI } & \multicolumn{12}{|c|}{ Panjang Antrian (m) } \\
\hline & \multicolumn{4}{|c|}{ Pagi } & \multicolumn{4}{|c|}{ Siang } & \multicolumn{4}{|c|}{ Sore } \\
\hline & $\mathrm{U}$ & $S$ & $\mathrm{~T}$ & B & $\mathrm{U}$ & $\mathrm{S}$ & $\mathrm{T}$ & B & $\mathrm{U}$ & $\mathrm{S}$ & $\mathrm{T}$ & B \\
\hline $\begin{array}{l}\text { Kondisi saat } \\
\text { ini }\end{array}$ & 89,8 & 85,7 & 82,5 & 119,0 & 84,6 & 83,9 & 83,3 & 119,2 & 87,1 & 92,5 & 83,9 & 120,4 \\
\hline $\begin{array}{l}4 \text { fase dengan } \\
\text { pelarangan } \\
\text { parkir }\end{array}$ & 77,9 & 77,3 & 78,1 & 91,0 & 67,4 & 67,7 & 75,9 & 81,1 & 76,9 & 83,3 & 74,7 & 88,3 \\
\hline $\begin{array}{l}3 \text { fase dengan } \\
\text { pelarangan } \\
\text { parkir }\end{array}$ & 49,0 & 48,4 & 68,8 & 67,5 & 40,5 & 40,0 & 49,1 & 65,8 & 48,0 & 47,5 & 67,3 & 71,7 \\
\hline
\end{tabular}

\section{Kesimpulan}

Dalam penelitian ini diperoleh kesimpulan sebagai berikut :

1) Kinerja Simpangan Patal saat ini tergolong buruk. Hal ini dapat dilihat dari Tingkat rata-rata Derajat jenuh (DS) 0.70, Panjang Antrian rata-rata mencapai 94,33 meter dan rata-rata waktu tundaan 57,46 smp/jam (ITP E)

2) Penerapan Pelarangan Parkir disekitar kaki simpangan dapat meningkatkan kinerja suatu simpangan yang dapat diukur dari nilai Derajat Kejenuhan, Panjang Antrian dan waktu tundaan.

\section{Daftar Pustaka}

1) Departemen Pekerjaan Umum, 1997, "Manual Kapasitas Jalan Indonesia ".

2) Hobbs. FD, 1995, “ Perencanaan Teknik Lalu Lintas “, Gajah Mada University Press, Yogyakarta.

3) Morlok Edward. K, 1991, "Pengantar Teknik dan Perencanaan Transportasi ", Erlangga, Jakarta.

4) Munawar Ahmad, 2004, "Manajemen Lalu Lintas Perkotaan", Beta Offset, Yogyakarta.

5) Oglesby. CH dan Hicks. RG, 1998, “ Teknik Jalan Raya “ Erlangga, Jakarta.

6) PT. LAPI GANANESHATAMA, 2009, "Rencana Tata Ruang Wilayah Kota Palembang".

7) Tamin. O.Z, 1997, Perencanaan dan Pemodelan Transportasi, ITB Bandung. 